\title{
Gentrification Impact to the Community's Quality of Life in Semarang Old Town
}

\author{
Dewi Santy Paulla ${ }^{*}$,Kurniawati Wakhidah \\ Urban and Regional Planning Department, Diponegoro University, Semarang, Indonesia
}

\begin{abstract}
The revitalization of the Old Town of Semarang is to support the Old Town as a heritage tourist destination and to overcome environmental problems such as tidal flood, slums, old buildings that are not maintained, and street vendors. Revitalization efforts have positive and negative impacts on the people in it. The positive impact caused by the existence of tourism activities in the Old Town area is the developing economy of Semarang City. While the negative impacts caused are physical, economic, and social gentrification; and affect the quality of life of local people. So it is necessary to study the relationship between gentrification and the quality of life of the community. The analysis to achieve that goal is the identification of revitalization, gentrification, and quality of life of the communities. Data collection methods were questionnaires, field observations, interviews, and document review, and also analysis techniques in the form of spatial planning. Based on the results of the study, there is relationship between gentrification and revitalization. That is, the facilities in the Old Town area cannot reach all levels of the people who live there. Besides, the presence of gentrification worsens the quality of life of local people. The government is still only focused on the physical development of the Old Town but has not considered the community's economic and social revitalization.
\end{abstract}

Keyword : revitalization, gentrification, quality of life

\section{Introduction}

Semarang Old Town is one of the areas that was developed as one of the heritage tourism destinations. But due to several problems such as tidal flood, slums, old buildings that are not maintained, street vendors who do not regularly make this area less developed. This

\footnotetext{
*Corresponding author: santy.paulla.dewi@pwk.undip.ac.id
} 
then underlies the Semarang City Government to revitalize the Semarang Old Town. The revitalization has been carried out from 2017 to 2019 where the emphasis is on physical improvement of the area such as road improvement, drainage, addition of signage and street furniture. While renovation of ancient buildings carried out by the respective building owners. The results of this revitalization are beginning to be seen where better physical appearance, proper infrastructure and facilities, flood and tidal flooding, street vendors' arrangement, and well-preserved ancient buildings. The Old Town of Semarang has become one of the mainstay tourist destinations where increasingly attractive tourists, seen from the increasing number of tourists.

The implications of this revitalization are changes in spatial use, changes in activities, increased prices and land rent. In addition, there are also migrants who live in this area and work there. Ancient buildings that were previously occupied illegally by the community began to be arranged and renovated. Furthermore leased or used as a place of business. Economic activities, especially those related to tourism, began to develop. The real thing that happened was an increase in land prices and building rent. In the end, not all people are able to live or rent buildings in this area. They are then displaced. All symptowns above indicate gentrification occurs in Semarang Old Town.

Gentrification is the process of changing an area that previously experienced a decrease in the quality of the physical environment and is inhabited by low-income people and then becomes a better region because of physical and economic intervention [1]. Likewise, this process also attracts migrants who generally have a higher economic background to work and live. Before revitalization, the activities of the Old Town area of Semarang took the form of offices, tourism, services and settlements. But after revitalization, tourism activities become more dominant compared to other activities. Hence, this change in activity affects socio-economic aspects such as the emergence of economic businesses and livelihoods.

The dominance of tourism activities on the one hand has a positive influence such as an increase in the number of tourists and generate new economic activities. But on the other hand it also has a negative influence such as the increasingly difficult to do loading and unloading for warehouse owners or business owners in the area because the concept of tourism in the Old Town is pedestrian, thus expanding pedestrian paths and road width for vehicles is increasingly limited.

Residential settlements are also increasingly limited due to increased taxes and increasing building rent. People who previously lived illegally in ancient buildings are trying to find a place to live around the Old Town area. In the end, the villages around the Old Town became increasingly crowded. These villages are inhabited by low income people who work in the informal sector (street vendors selling food, pedicab drivers, parking attendants) in Kota Lama. This then indicates that gentrification affects the quality of public health. Gentrification does not only affect physical, social, economic aspects, but also the aspects of public health (resident health outcome) [1]. The definition of public health here is in a broader context, which concerns healthy living conditions, occupancy density, availability of green open space, as well as the financial capacity (socio-economic) of the community which can be identified through types of employment and income [1-3]. This study attempts to analyze the effect of gentrification on city's health in the Old Town of Semarang. City's health here is not interpreted narrowly in the context of community life expectancy or number of people who are sick, but more than that such as housing conditions, density of homes, availability of public open space, and socioeconomic capabilities. 


\section{Aims and Purpose}

The purpose of this study is to examine the relationship between gentrification and the quality of life of the community. The targets to achieve the research objectives are to identify the revitalization carried out in the Semarang Old Town area, analyze the gentrification that occurred and the relationship with the revitalization that has been carried out, and analyze the relationship between gentrification and the quality of life of the community.

\section{Method}

The research methods used are quantitative and qualitative. Data collection methods used in the study are questionnaires, field observations, interviews with BPK2L, and document review. Data collection was carried out prior to the Covid-19 pandemic. The questionnaire was used to find out people's perceptions of changes in socio-economic conditions that were felt after the revitalization, field observations were used to directly observe the condition of the Old Town area of Semarang, interviews with BPK2L were used to find out information about the revitalization activities that had been carried out, and document review was used. to get data on land use up to the value of land in the Semarang Old Town area through Google Street View and several related websites. The analysis technique used in the study is spatial planning. Spatial planning is used to describe the location and form of revitalization carried out in the Old Town Area to explain the gentrification that is happening.

The stages of analysis in this study are identifying the revitalization carried out by the government; what is done and everywhere. Next analyze the symptoms of gentrification by mapping changes in spatial use and changes in activities and changes in land prices or building rent. The results of this gentrification analysis are evaluated by revitalizing the area map so that the findings of the revitalized area are also experiencing gentrification; this shows that there is a correlation between revitalization and gentrification. Then, analyze the relationship between gentrification that occurs with aspects of city's health.

\section{Result and Discussion}

\subsection{Semarang Old Town Revitalization}

Semarang Old Town belongs to the historical area of Semarang, which is an urban growth embryo history. Semarang Old Town is a historical heritage of the growth of the Semarang City which has high architectural, aesthetic, scientific and cultural values that need to be preserved and reorganized in a directed direction. Semarang Old Town was the seat of government in the Dutch colonial era [4]. Semarang Old Town was included as one of the World Heritage Site nominations by UNESCO in 2016, and is currently submitting requirements to become a world heritage site [5].

Efforts to escape the Semarang Old Town area are regulated in the Old City Building and Environmental Planning Plan (RTBL) listed in Semarang City Regional Regulation No. 8 of 2003. The regulation was used as a guideline for the development of the Old City 
area and as a legal basis for implementing the Old Town area building and environmental management program. One of the goals of the regional regulation is to develop the Old Town area as a vibrant historical area that allows for modern economic, social, cultural and tourism activities in architectural and environmental settings as part of the history of Semarang City. In addition, the regional regulation is expected to be used to achieve spatial use with a mixed use pattern that is suitable for the conservation and revitalization of historical-cultural areas..

Based on Semarang City Regulation No. 8 of 2003, the Old Town planning area was set to be around 40 hectares covering the Old Town area of about 31 hectares and the Influence Area of around 9 hectares (see Fig. 1). The boundaries of the Semarang Old Town planning area consist of the Tawang Train Station and the northern rail line to the north; Jl. Haji Agus Salim to the south; Jl. Colonel Sugiyono, Jl. Empu Tantular, and Semarang River on the west; and Jl. Ronggowarsito, Kampung Permasan, and Grogolan Village in the east. The Semarang Old Town planning area consists of three sub-districts from two sub-districts in the city of Semarang, namely Bandarharjo and Tanjung Mas sub-districts which are included in the North Semarang sub-district; and Purwodinatan Urban Village which is included in Central Semarang District.

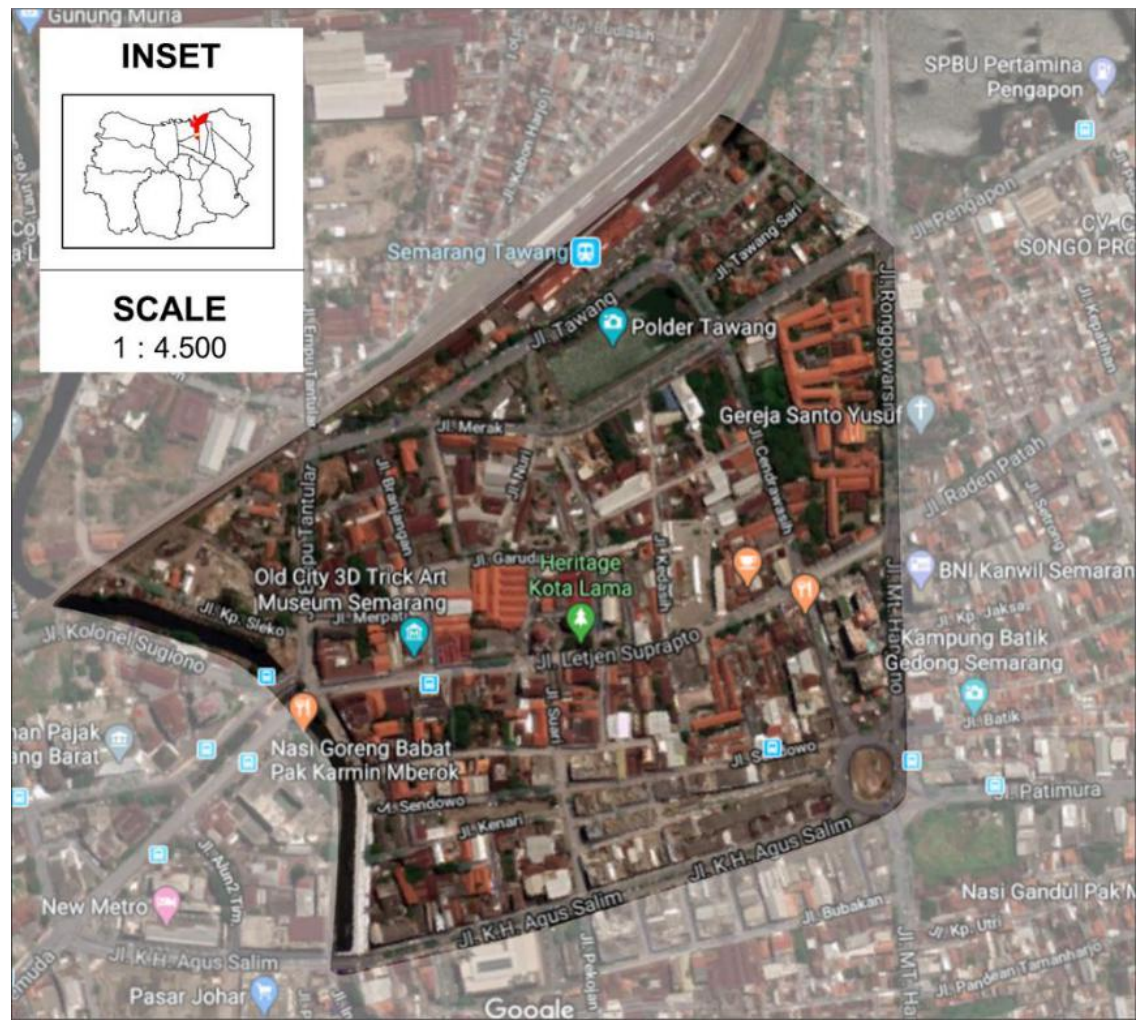

Fig. 1. Semarang Old Town Planning Area

Regional space utilization plan stipulated in Semarang City Regional Regulation No. 8 of 2003 [6] concerning RTBL Semarang Old Town area covering the function of residential, trade and office functions, and recreational and cultural functions. Map of the 
plan for spatial use of the Old Town area of Semarang can be seen in Fig. 2. The utilization of the space is divided into 5 (five) segments as follows.

a. Segment I, Culture area, located on Jl. Let. Jend. Suprapto;

b. Segment II, Creativity area, located around Jl. Tawang, Jl. Merak, Jl. Garuda, Jl. Nuri, Jl. Srigunting and Jl. Bird of paradise;

c. Segment III, Commercial and Office area, located around Jl. Mpu Tantular, Jl. Nuri and Jl. Garuda, the north side of the Berok Bridge to the boundary of the planned translucent route along the Tawang railway line J1. Colonel Soegiono;

d. Segment IV, Office, Commercial and Traditional Trade area, located around J1. Mpu

Tantular, South side, Jl. Kepodang and Kawasan Jurnatan;

e. Segment V, Modern Commerce, Education and Offices area, is located around J1. Haji Agus Salim, Bundaran Jurnatan, Jl. MT. Haryono, Jl. Ronggowarsito, J1 ,. Widoharjo and part of Jl. Cendrawasih.

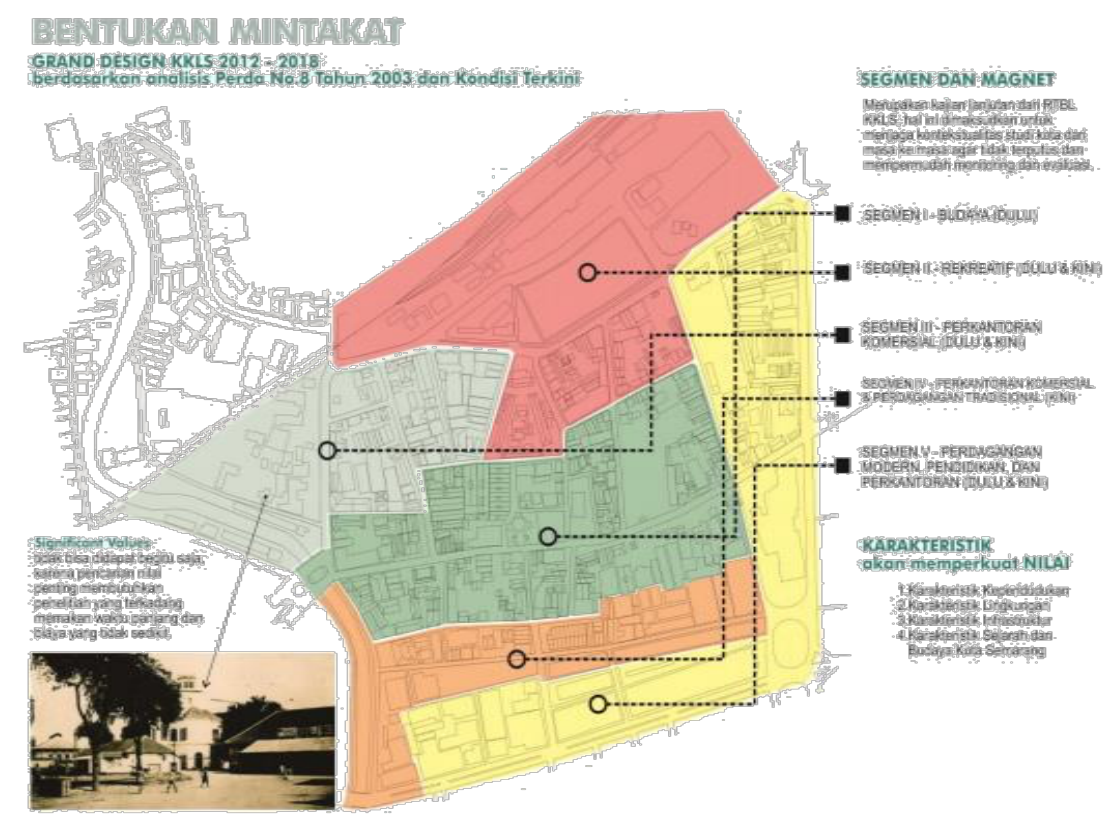

Fig. 2. Map of Semarang Old Town Area Spatial Planning Plan [7]

The form of the Semarang City Government's effort in revitalizing the Old Town area according to Semarang City Regional Regulation No. 8 of 2013 concerning the RTBL of the Old Town Region is to provide public infrastructure and facilities in the Old Town area planning area which consists of providing public roads, parking, clean water, drainage, waste water management, waste management, and providing public open space. Efforts to revitalize the provision of public roads in the form of complete landscaping, signs, road furniture, pedestrian safety benches, visual free of infrastructure, the establishment of pedestrian-only lanes, making of translucent roads, repairing bridges by maintaining their original shape and location. Efforts to provide parking in the form of establishing a linear parking area and establishing open parking. Efforts to provide clean water in the form of planting secondary and tertiary clean water networks, installing hydrants, and setting bong wells.

Efforts to provide drainage by providing drainage systems using polders which include retention ponds, primary, secondary and tertiary canals; water pump installations, 
and sluice gates in the Tawang and Kali Baru retention ponds. Efforts to treat wastewater by channeling an integrated WWTP pipeline system. Efforts to manage waste by placing Temporary Garbage Collection Sites (TPS) in the form of containers that are easily moved. Efforts to provide public open space in the form of parks, retention ponds, and Semarang River. Management of the planning area is carried out by the Old Town Regional Management Agency (BPK2L) which involves elements of the government, private sector and the community with the aim of reviving, restoring, maintaining and developing various functions and values of the building. BPK2L has the authority to conserve and revitalize the area, which reports directly to the Mayor. Funding for the management of the area comes from the Government, third party donations, and other legal sources.

Revitalization carried out by the Semarang City Government is carried out in two stages, namely stage I in 2016 - 2018 and phase II in 2019 - 2020. The form of efforts undertaken by the Semarang City Government in phase I are improvement of drainage and roads, installation of andesite stones, provision of lighting lights and street furniture on the streets of the Old Town area. While the form of phase II revitalization efforts undertaken by the Semarang City Government which continues to this day are road improvements outside the Semarang Old Town area, the construction of a Berok Pump House, and the construction of a museum at the Bubakan Roundabout. The following is a map of the revitalization points that have been carried out by the Semarang City Government (see Fig. 3).
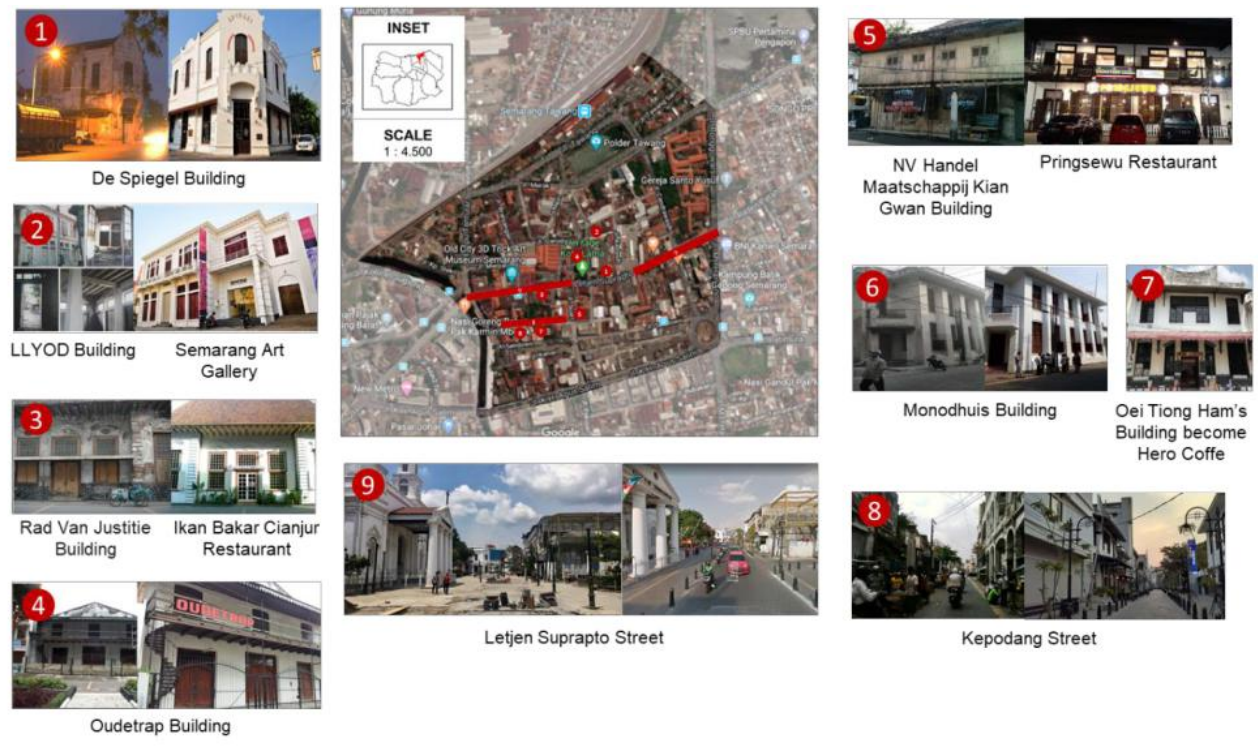

Kepodang Street

Fig. 3. Revitalization Map of the Old Town Area

\subsection{Gentrification and Relevance with Revitalization in the Semarang Old Town}

Revitalization is an effort to revive ancient areas, buildings, roads and environments by implementing new functions in the original architectural arrangement to enhance economic, social, tourism and cultural activities. One of the revitalization activities is the establishment of tourism activities [8-10]. Heritage tourism activities are able to have positive impacts on improving the economy of the communities, and social impacts [11]. However, there is also a negative impact due to tourism activities, that is the decreasing quality of life of the local community. 
Revitalization has several stages, namely physical intervention, economic rehabilitation, and social / institutional revitalization [12]. Revitalization carried out in the Semarang Old Town area still tends to be physical intervention and social revitalization, there are still problems in the stages of economic rehabilitation and social revitalization. Physical intervention carried out by the Semarang City Government is to provide facilities and infrastructure for the Old Town area which includes the provision of public roads, parking, clean water, drainage, waste water management, waste management, and provision of public open space. This is done as a basis to support tourism activities that will be developed. In connection with economic rehabilitation, the Semarang City Government has managed historic buildings by changing the function of historic buildings that were previously neglected to now become areas of trade and services such as cafes, art exhibition halls, and restaurants. The revitalization efforts undertaken by the Semarang City Government are not only with conservation activities, namely maintaining, restoring, improving the appearance and function of historic buildings in the Old Town area; but also changes the function space to become a commercially viable area. Through these efforts, there is a sense of ownership (sense of belonging) and a sense of wanting to care for the building that has been conserved by the people who use the building. The change of function of building space into a trade and service area has an indirect impact on the economy of Semarang City. Trade and services are considered capable of being used as a driving force for tourism [10], [13-16] more tourists come the more trading activities are carried out. These activities can improve the economy of Semarang City. Therefore, efforts to revitalize the Old Town area by changing the function of space to trade and services can make the existing economy can be rehabilitated.

But on the other hand, economic rehabilitation cannot be felt by local people living in the Old Town area. Local people cannot afford to rent the conserved building to be used as space for trading activities. People who are able to rent the conservation building are people from outside the Old Town area. One of the revitalization efforts undertaken by the Semarang City Government is the provision of public roads, in the form of equipping roads with landscaping, signs, road furniture, and pedestrian safety benches. The revitalization of the road and pedestrian is the widening of the pedestrian to provide pedestrian comfort with pedestrian pavement and the road along the pedestrian is paving (see Fig. 4). Revitalized roads are roads that were originally used by the local community in the Old Town area as a space for selling. So it is necessary to curb Street Vendors (PKL) that exist along the revitalized roads, which are local communities in the Old Town area. In fact, $96 \%$ of the people living in the Old Town area are entrepreneurs who own food stalls, antique sellers, and other small micro businesses. So becoming a street vendor is a job to get the main income of the local community. Control of street vendors is not accompanied by the provision of relocation land, so that local people who get income from trading into street vendors, are now reduced in income and those who turn to find another job. 


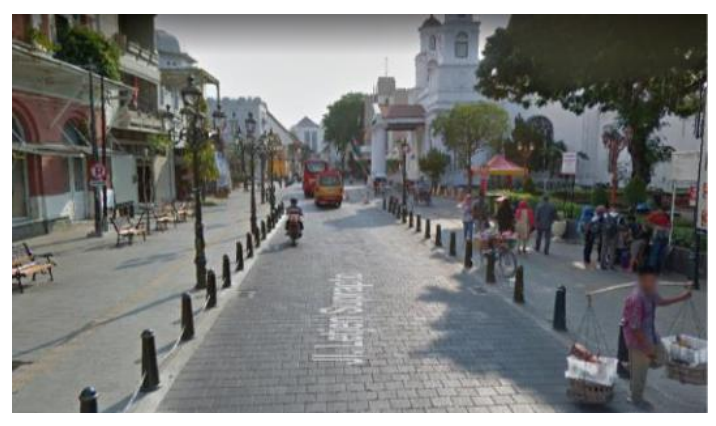

Fig. 4. Revitalizing the Pedestrian of the Old Town Area and Letjen Suprapto Street

The Semarang City Government has provided access to public transportation that passes through the Old Town area, namely Trans Semarang. The Trans Semarang route that passes through the Old Town area of Semarang can be seen in Fig. 5. However, there is no integration between public transportation and environmentally friendly transportation that has existed for a long time in the Old Town area, namely the becak. Before the revitalization of the Old Town area, many local people living around the Old Town area worked as pedicab drivers. After the revitalization, public transportation is well available and the existence of communal parking that can accommodate private vehicles becomes an obstacle to dim the becak's existence. To overcome this, the Semarang City Government can make the pedicab as a compulsory transportation that must be used for tourists who come in the Old Town area. The Semarang City Government can facilitate pedicab drivers by making a pedicab communal parking near private vehicle parking and a public transportation stop. Through this coordination, the development of the Old City area can be sustainable and local people can enjoy the benefits of the conservation of the Old Town area. 


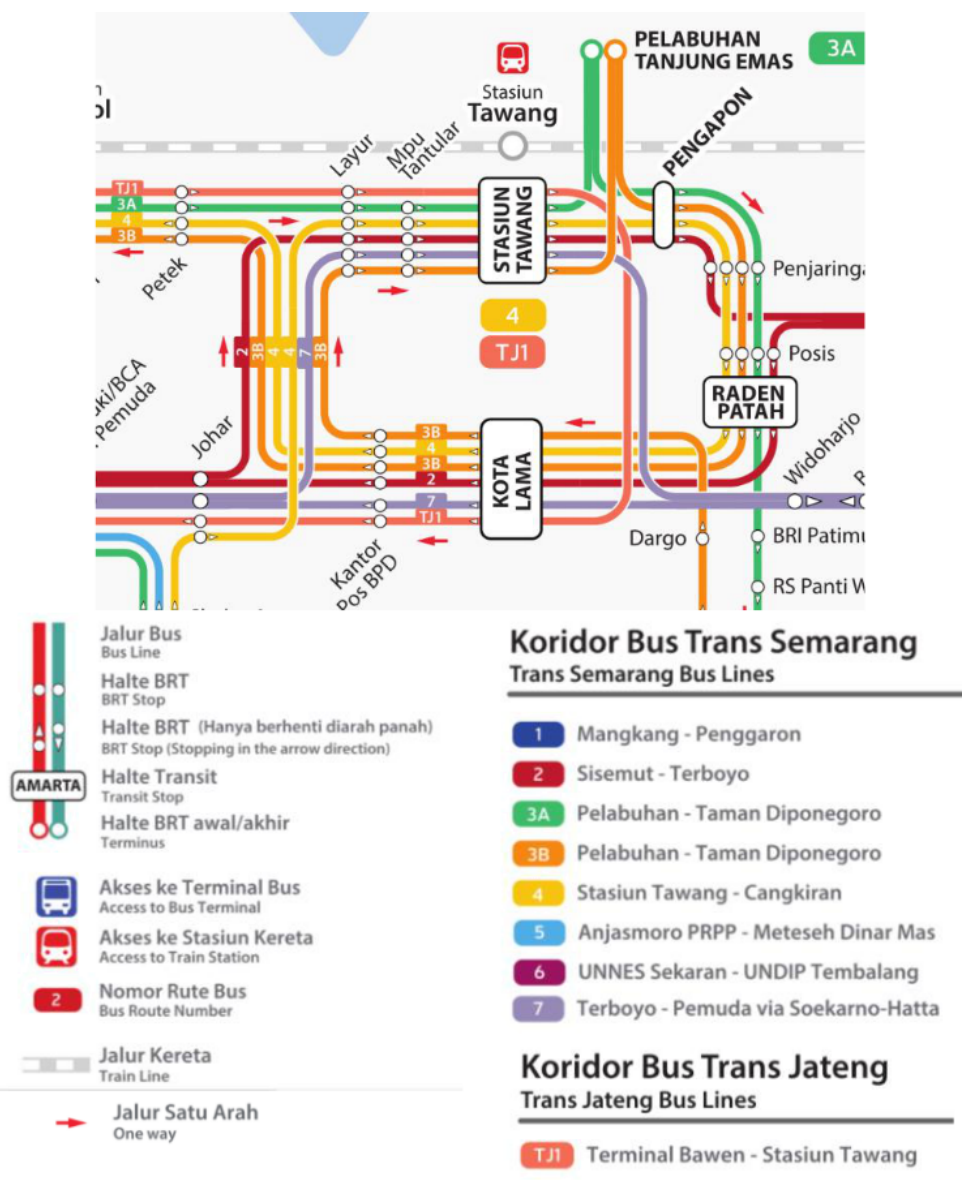

Fig, 5. Trans Semarang route that passes through the Old Town area [17]

In connection with social revitalization, the Semarang City Government is able to create an attractive environment in the Old Town area through historic buildings that have been conserved. So that Kota Lama has a positive impact on the people of Semarang City. The Old Town area can be a mainstay tourist attraction of the Semarang City that must be visited. The social conditions of the local community in the Old Town area are identical with negative activities, such as the many nighttime entertainment activities and cockfights. With the revitalization, there was a social change in the local community in the Old Town area, in which there were no more such activities. However, if it is associated with economic rehabilitation, then the local people who initially used night entertainment and cockfighting activities as a source of income, are now also looking for other jobs or doing these activities elsewhere. Based on the results of interviews with the coordinator of the empowerment of the Old Town area, the revitalization of the Old Town area is not accompanied by improvements in the human resources living in the Old Town area. The old work of the local community has not changed, there are local people who used to be thugs and are still thugs, and local people who used to be commercial sex workers (CSWs) are now also CSWs. However, the Old Town area community has tried to increase the capacity of the local community, one of which is the training of thugs to be a tour guide with funding from the community and without government assistance. 
Based on the explanation of the stages of revitalization carried out by the Semarang City Government, it can be seen that the implications of the revitalization of the Old Town area are changes in spatial use, changes in activities, increased prices and land rent. More and more activities taking place in the Old Town area make Old Town a lot of investors viewed to invest in the Old Town area, namely the use of buildings from what was originally empty into restaurants and cafes. There is also a change in land use into offices. This makes the value of land in the Old Town area increases. Map of the land value zones of the Old Town area can be seen in Fig. 6.

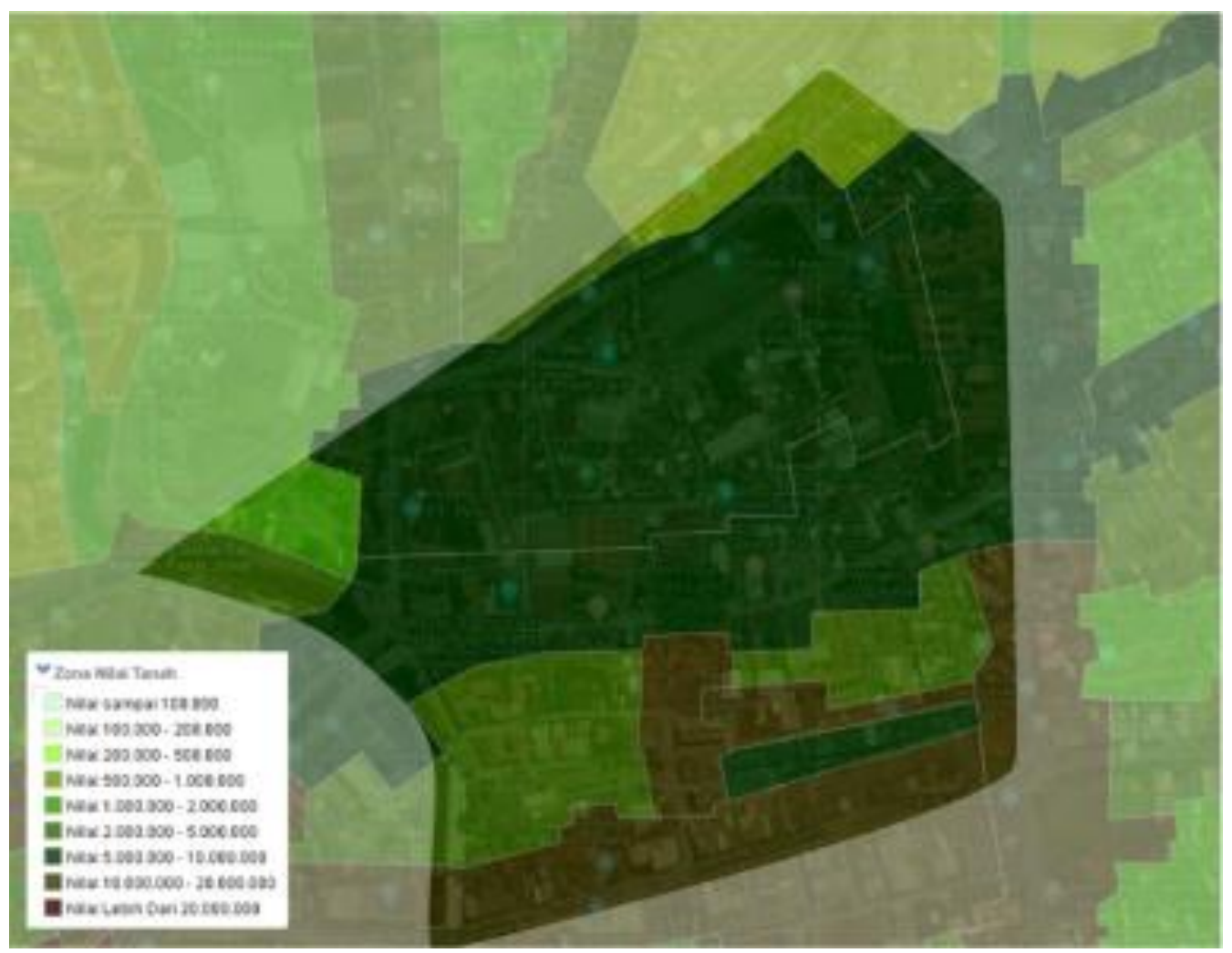

Fig. 6. Land Value Zone Old Town Area [18]

Based on the land value zone map (see Fig. 6), it can be seen that the value of land zones in the Old Town area is in the range of 500,000 to more than 20,000,000 rupiah per square meter. Zones that have a land value of 500,000 - 1,000,000 are zones with land use as settlements, service trade, and vacant land. Settlements and trade services are along Kp. Sleko Street Settlements in the zone are middle to lower class communities, where the use of old buildings that have not been used as dwellings for a long time. In addition, trade and services in the zone consist of food stalls, grocery stalls and private offices (see Fig. 7). Based on parcels based on rights according to the Ministry of Agrarian Affairs and Spatial Planning / National Land Agency, buildings used as residential and trade services along Jl. $\mathrm{Kp}$. Sleko has not been registered in the parcel data based on rights, so it can be seen that there are land and buildings that are not known to their owners and are used by others without the owner's knowledge. 

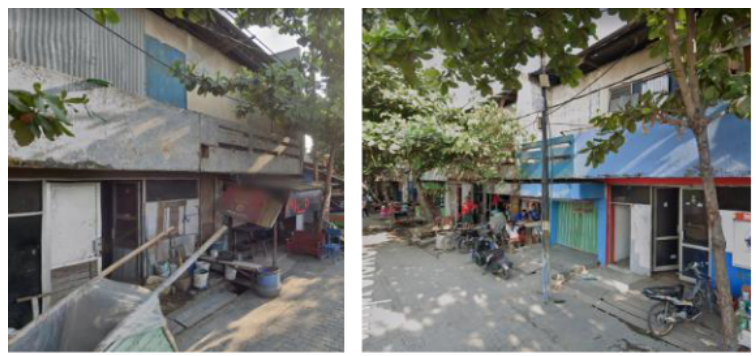

Shophouse and Settlement

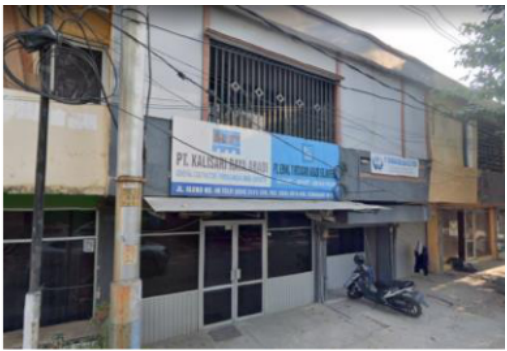

Private Offices

Fig. 7. Land Use Zone Value of Land 500,000 - 1,000,000

The zone that has a land value of 2,000,000 - 5,000,000 is a zone with the use of space as residential, trade services, and vacant buildings. This zone passes several roads, namely Sendowo Street, Kepodang Street, and Kenari Street. Spatial utilization in this zone can be seen in Fig. 8. On Sendowo Street (east), the use of space as a service trade. Along this road, there are many empty buildings that are not used. So that in the front area of the empty building is used as a place to sell food, used equipment, and junk. While the use of space on Sendowo Street (west) as an office and trade services. The use of space on Kenari Street is as a service trade in the form of karaoke, junk warehouse, and food stalls. This area is the dirtiest area among other areas in the Old Town area. In this area, it is still a place for commercial sex workers and liquor sales. Based on the results of field observations, it can be seen that the more empty buildings that are not used, the more the use of building space as illegal dwelling and the use of the building's front space as a place to sell. In addition, the use of space in Kepodang Street is as trade and services such as cafes, museums and multipurpose buildings. After the Kepodang Street was revitalized, the image of Jalan Kepodang Street which was originally a place for cockfighting and illegal street vendors, has now become a positive place, which is a hangout and a place for tourists to visit.

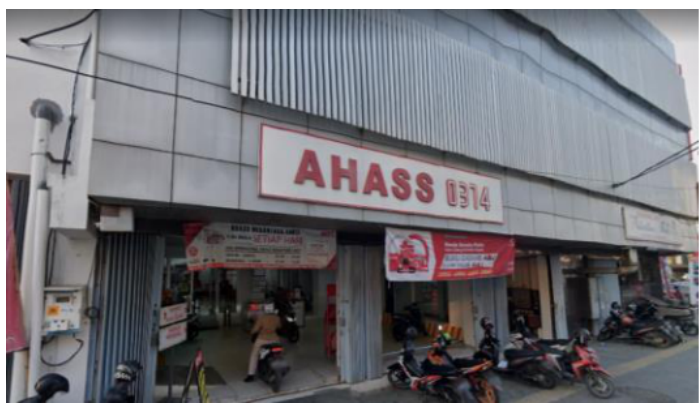

Trade and Services in Sendowo Street (East Side)

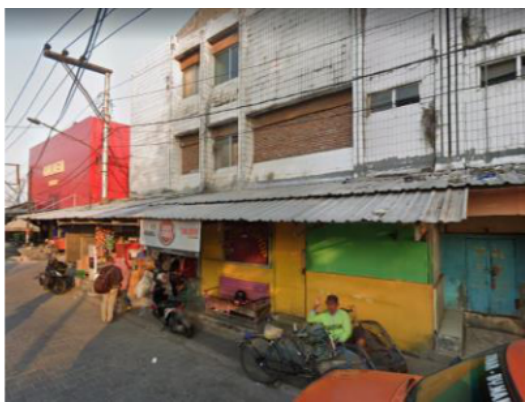

Trade and Services in Sendowo Street (West Side) 


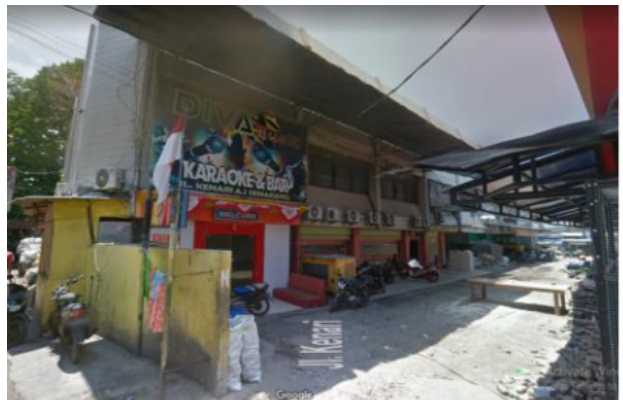

Karaoke Lounges in Kenari Street

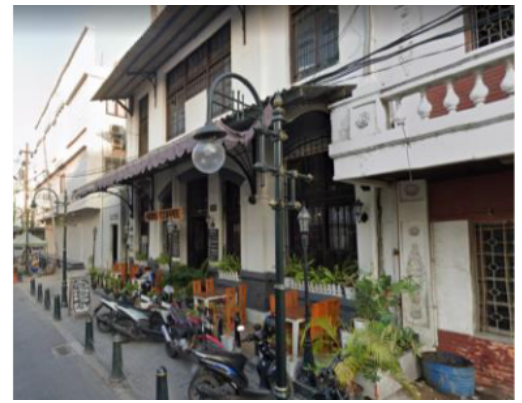

Café in Kepodang Street

Fig. 8. Land Use Zone Land Value 2,000,000 - 5,000,000

About $65 \%$ of the land in the Old Town area is a zone that has a land value of 5,000,000 $-10,000,000$. Spatial use in the land value zone of 5,000,000 - 10,000,000 is mostly located in the northern and central part of the Old Town area. The spatial use in this zone is offices, trade and services, and public parks (see Fig. 9). Offices in this zone are in the form of cigarette factories, BUMN, and other private companies. Trade in services in this zone in the form of cafes, restaurants, lodging, and museums. While the public parks in this zone are Taman Srigunting, Garuda Park, Polder Tawang, and other public parks. This zone is the heart of tourism activity in the Old Town area. Utilization of the existing space in this zone is largely a supporter of tourism activities, namely as a tourist attraction and supporting tourist activities such as restaurants and lodging places.

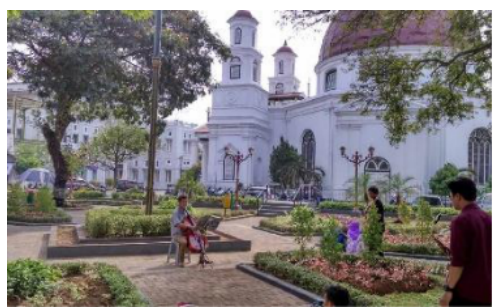

Taman Srigunting Park

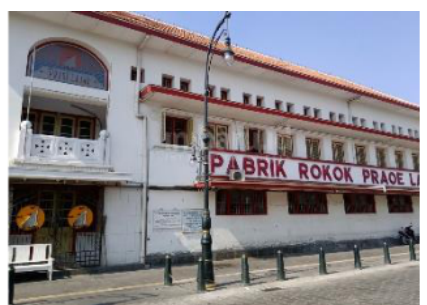

The Praoe Lajar Cigarette Factory

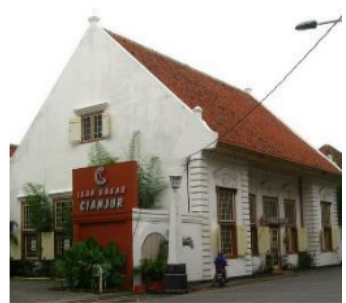

Ikan Bakar Cianjur Restaurant

Fig. 9. Land Use Zone Value of Land 5,000,000 - 10,000,000

The zone which has a land value of more than 20,000,000 is located south of the Old Town area. The use of space in the zone is trade and services. This zone has a high land value because this zone is crossed by Kyai H. Agus Salim Street which is a collector street in Semarang City, which connects Jalan Pemuda and Bubakan Roundabout. This road is the most motorized road compared to other roads in the Old Town area. So this makes this zone has the highest land value compared to other land in the Old Town area. Buildings along Kyai H. Agus Salim Street are used as trade and services (see Fig. 10). 

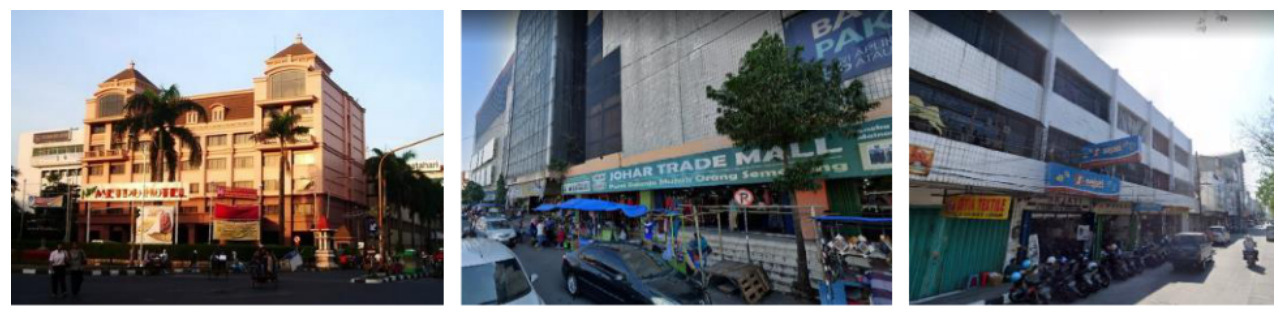

New Metro Hotel Shopping Center Johar Shophouse along Kyai H. Agus Salim Street

Fig. 10. Land Use Zones More than 20,000,000

\subsection{Gentrification and Relevance with Quality of Life}

Efforts to revitalize the Old Town area by the Semarang City Government have a goal to overcome various existing problems, including tidal flood, slums, old buildings that are not maintained, and irregular street vendors. The revitalization effort is carried out by developing tourism in the Old Town area. Revitalization efforts have positive and negative impacts on the people in it. The positive impact caused by the existence of tourism activities in the Old Town area is the increasing economy of Semarang City, namely the increasing number of tourists who come to visit the Semarang Old Town. The tourism industry is considered capable of creating a multiplier effect because tourism is related to other industries.

However, there are negative impacts caused by others due to tourism activities, namely the existence of gentrification (the displacement of local residents due to tourism growth that occurs). This gentrification arises is the movement of local people who reside in the Old Town area to another place. This gentrification occurs due to the existence of revitalization, which is a change in the function of the building that will function properly. Empty buildings that have high architectural value and have the potential to be developed are altered their use of space to accommodate activities that support tourism in the Old Town area, such as tourist attractions, restaurants, cafes, lodging, places to sell goods and other services. However, there are people who before the revitalization lived illegally in ancient buildings in the Old Town area. Therefore, the community lost its place of residence and tried to find a place to stay around the Old Town area. The inability of local people to buy or rent buildings in the Old Town area, making the local people move to other empty buildings or villages around the Old Town area. This affects the quality of public health [1]; where local communities have inadequate physical housing conditions, increasing numbers of local people living in one place, the unavailability of public open space, and lack of socioeconomic capacity. The living conditions of the local community in the Old Town area can be seen in Fig. 11. 


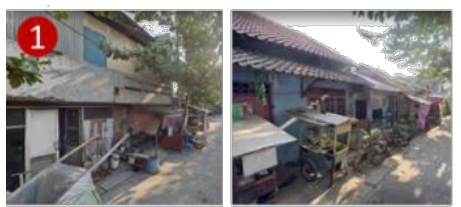

Slum Area in Kp. Sleko Street

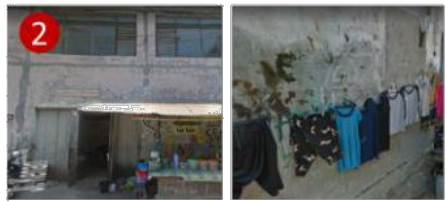

Slum Area in Kenari Street

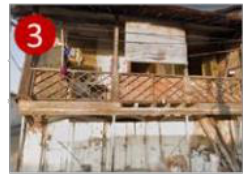

Taman Srigunting Street

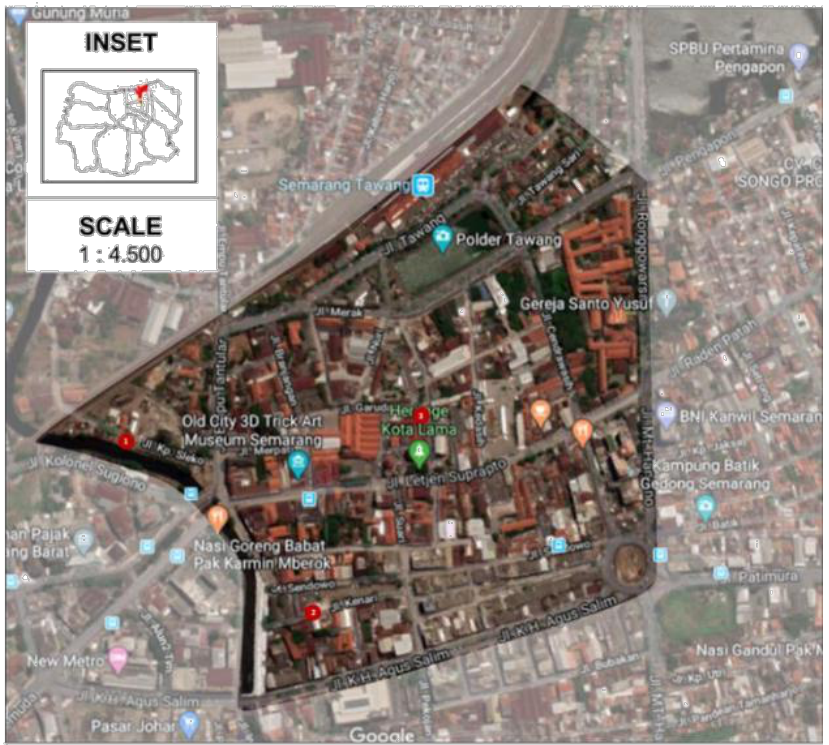

Fig. 11. Conditions of Occupancy of Local Communities in the Old Town Area

Based on the picture of the condition of local community dwelling in the Old Town area, there are two types of community dwellings, namely in the form of landed houses and the use of ancient buildings. The houses in Sleko Village consist of tread dwellings and the use of ancient buildings. Sleko village is located in the Bandarharjo Village. Tread houses built by local people can be known through the modern architecture of the inhabited houses, while the use of ancient buildings can be seen through Chinese architectural buildings, namely the concept of shop houses. There are two differences between the physical condition of the landed house and the old building, namely the site of the site looks to meet the requirements of a healthy home, which has air ventilation, a tile floor, and a tile roof with good condition. While the ancient building which is used as a residence, does not have adequate air ventilation and there is no improvement on the building. The use of ancient buildings by the community is illegal, because the user is not known by the building owner. This can be known through the land that has not been registered in the parcel data based on the type of rights by the Ministry of Agrarian Affairs and Spatial Planning / National Land Agency. So that people who live there can be displaced at any time. However, there are tread houses to the west of Kampung Sleko (near the railroad tracks) with conditions that do not meet the requirements of a healthy home, namely wooden and plywood-based walls, cement plaster floors, zinc roofs, and inadequate air ventilation (see Fig. 12 ).
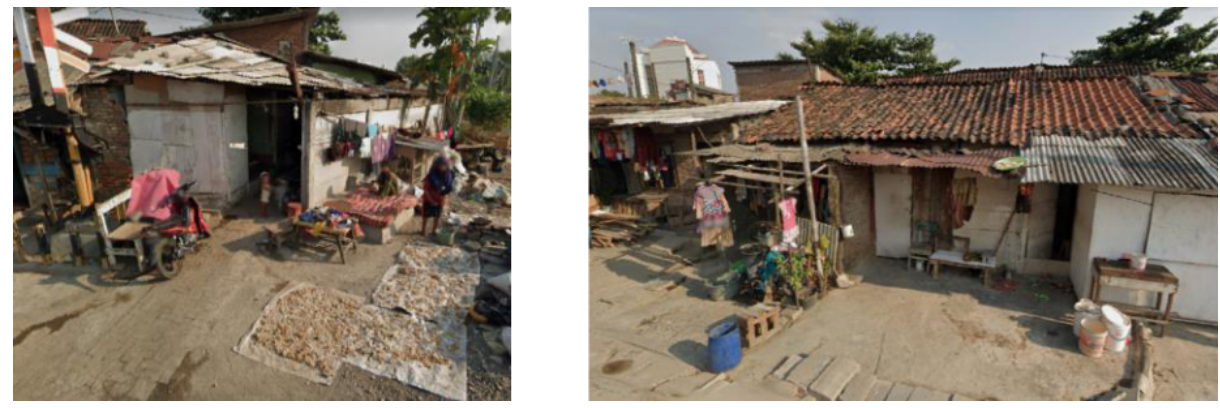

Fig. 12. The Condition of the Settlement in Sleko Street 
When viewed based on the environmental conditions of settlements, settlements along Jalan $\mathrm{Kp}$. Sleko is a slum area. This can be known through irregular use of existing space. There are street vendors along the road, the use of ancient building space that is the ground floor is a place to sell and the upper floor is used as a residence, there are carts in front of the house. This supports the statement of the phenomenon of gentrification, because people who live and sell along Jalan Kp. Sleko is an indigenous people who live with middle to lower economic conditions. In addition, related to land values, residential zones along Jalan Kp. Sleko has a land value of 500,000 - 1,000,000 rupiah / $\mathrm{m} 2$ (the zone with the smallest land value compared to other Old Town areas). In this neighborhood, there is no public space that can be used by the community to gather. The public space used is the road section (see Fig. 13). In the picture it can be seen that the road is used for relaxing and gathering, and children's playground.

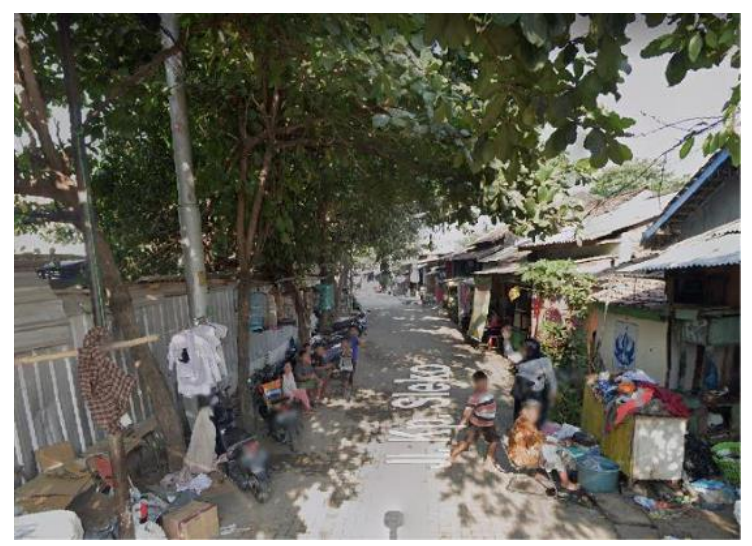

Fig. 13. Use of Roads as Public Spaces

Besides along Jalan Kp. Sleko, there are local people who live on Jalan Kenari. People illegally reside in ancient buildings. Same is the case with residential on Jalan Kp. Sleko, residents can be displaced at any time. Empty buildings that are not used by the owner, used for residence. This building belongs to the Purwodinatan Village. Based on the physical condition of the building, there was no improvement by the people who were staying to live in the building. So that the house used is in poor condition and does not meet the requirements of a healthy home, where there is no air ventilation, adequate lighting, and a ground-based floor. When viewed based on environmental conditions, this environment is included in the slum area. This can be known by the existence of goods outside the home, there is no pavement, and there is clothesline in front of the house. In addition, this residence is close to unfavorable social conditions, which is close to the rubble shed and karaoke lounges that provide liquor and a place for commercial sex workers (see Fig. 14). In addition, there are unused inhabitants of ancient buildings in buildings located on Jalan Taman Srigunting. 


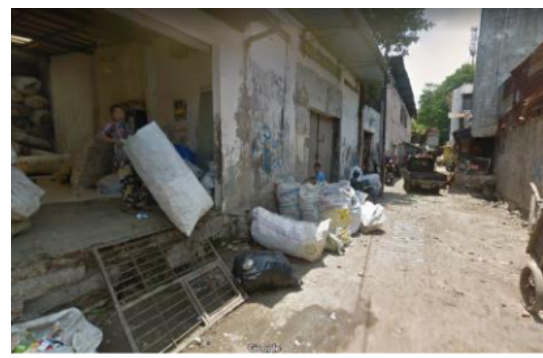

Rubble Shed

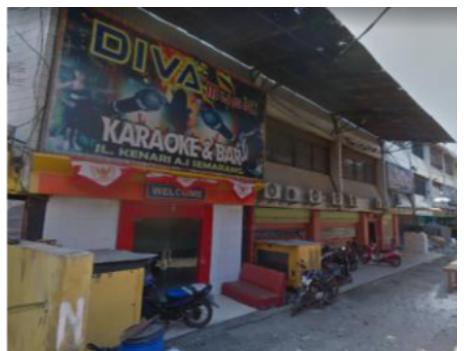

Karaoke Lounge

Fig. 14. Environmental Conditions Around the Kenari Street Residential

There are also other social problems, namely the existence of homeless people who live in random places in the Old Town area (see Fig. 15). In addition, the existence of tourism activities, facilities and infrastructure are not only used by people who live in the Old Town area of Semarang, but also by tourists who come. This can be a threat that is reducing the quality of life of local people. While based on the conditions in the field, it can be seen that not all people living in the Old Town area can access clean water (see Fig. 15). Based on the conditions in the field, people who live in Sleko Village collect rainwater using a bucket placed in front of the house, the water is used to wash dishes and clothes.

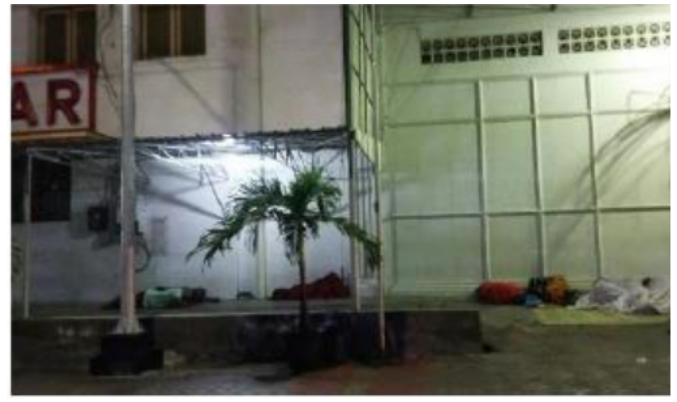

Homeless in front of Praoe Lajar Building

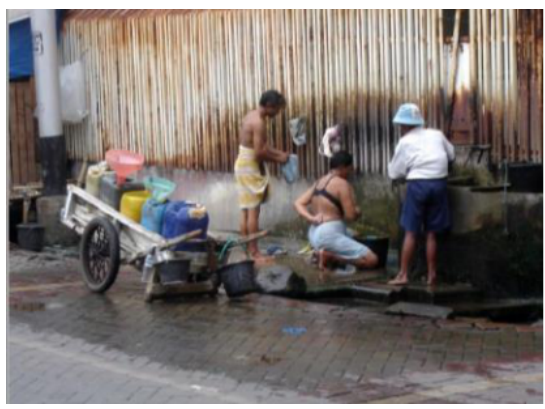

Utilization of Water Sources for Bathing

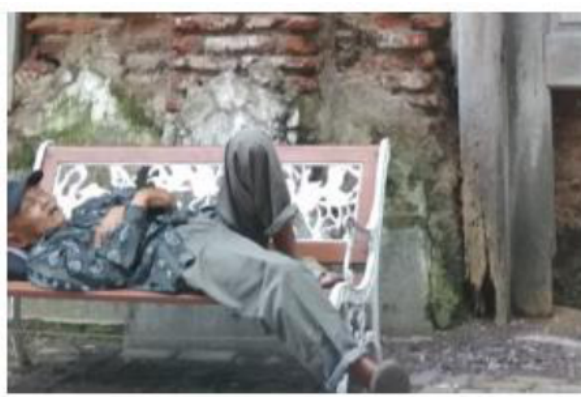

Homeless in Jalak Street

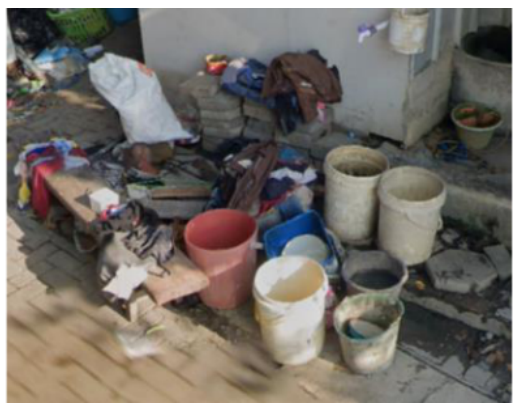

Rainwater Collection Using Buckets

Fig. 15. Social Problems and Water Utilization in the Old Town Area

Gentrification that arises in the Old Town area is not only about the movement of local communities in the Old Town area, but also relates to reduced access of local communities in improving the economy. Local people who were originally able to carry out trading activities in the Old Town area (PKL), are now unable to carry out these activities with the revitalization of the Old Town area. Revitalization leads to changes in residences, changes 
in livelihoods, and decreased income levels [19]; this happened in the Old Town area. The Semarang City Government provides land for selling at the Semarang Creative Industry Gallery (see Fig. 16). At the Semarang Creative Industry Gallery, a location with air conditioning is provided to pamper visitors. The Semarang City Government built this building to provide facilities for relocated street vendors. However, based on research results, more traders can access these facilities from outside the Old Town area. Based on the results of the study, as many as $15 \%$ of the community respondents who live in the Old Town area who have a business, stated that they do not have permanent land to sell their products.
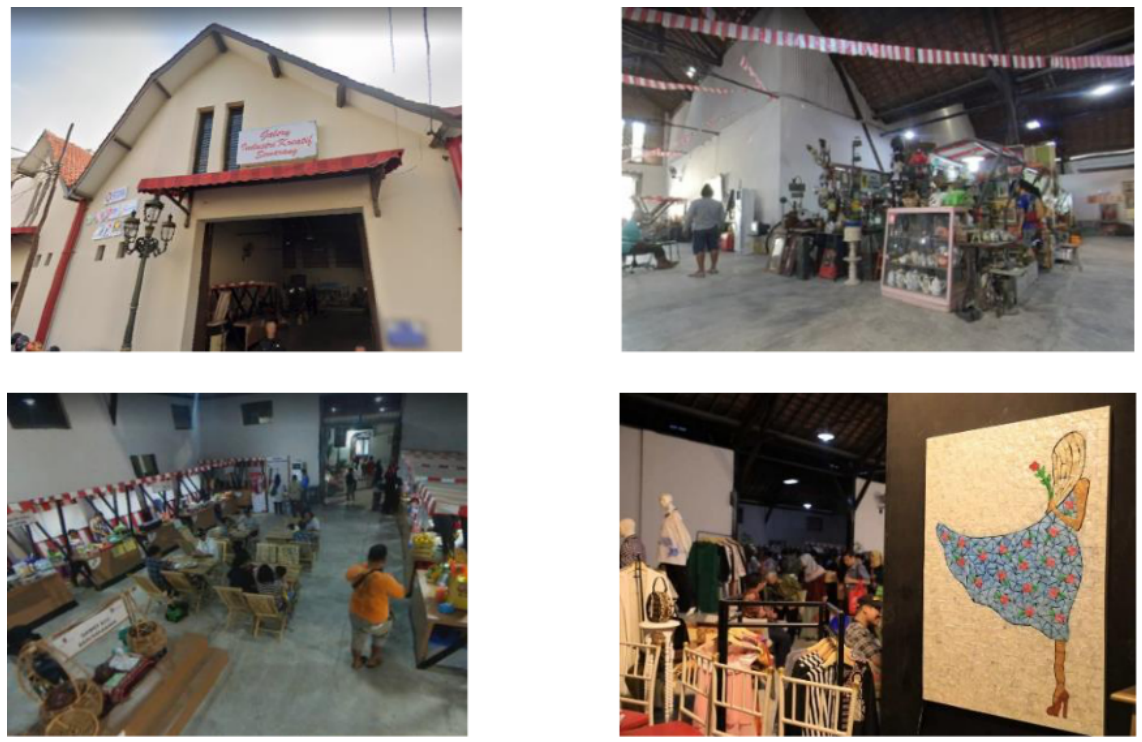

Fig. 16. Semarang Creative Industry Gallery in the Old Town Area

\section{Conclusion}

Based on the results of the study, there is a relationship between revitalization and gentrification. There is an impact of road revitalization in the Old Town area, namely the eviction of street vendors owned by local communities. The provision of facilities for selling Small and Medium Enterprises in the Semarang Creative Industry Gallery does not reach local people. These people sell there, people who live outside the Old Town area. Revitalization causes changes in land values so that local people who are middle to lower class are unable to rent buildings in the Old Town area to sell. Besides, due to revitalization, local people who use the empty old buildings as a place to live make people look for another place to stay, which is moving to another empty building or villages around the Old Town area.

In the Old Town area, communities live in a slum area settlement in Kp. Sleko Street and Kenari Street. Residential conditions along Jalan Kampung Sleko have houses that meet healthy house requirements and those that house conditions do not meet healthy house requirements. There are empty tread houses and old buildings that the local people use to live. Whereas the local people who live on Jalan Kenari, namely by utilizing ancient uninhabited buildings. The two locations' environmental conditions are quite poor due to 
the lack of public open space and adverse social conditions around the settlement. The social condition in the Kenari Street environment includes rubble shed, karaoke lounges that provide liquor, and a base of commercial sex workers.

Revitalization by the Semarang City Government is still limited to physical intervention, not yet considering the economic and social rehabilitation of local communities living in the Old Town area. However, the presence or absence of gentrification, the quality of life of people living in the Old Town area, is included in the bad category. Therefore, the intervention of the Semarang City Government is needed to revitalize the economy and society, not only physically. The provision of planned infrastructure must also consider the needs of the local community, not just consider tourists. That is because local people are people who can make tourism activities in the Old Town area sustainable. Through improving the quality of life of the local community in the Old Town area, there is also an increase in the potential for sustainable development of the Old Town conservation area to become national and international pride of tourism destination.

\section{References}

[1] M. Esther, C. Reid, M. S. Mujahid, and A. M. Allen, "Health \& Place ' Clear action requires clear thinking ': A systematic review of gentri fi cation and health research in the United States," Health Place, vol. 59, no. July, p. 102173 (2019)

[2] C. B. Swope and D. Hernández, "Housing as a determinant of health equity: A conceptual model,” Soc. Sci. Med., p. 112571 (2019)

[3] G. Mccartney, W. Hearty, M. Taulbut, R. Mitchell, R. Dryden, and C. Collins, "Regeneration and health : a structured, rapid literature review," Public Health, vol. 148, pp. 69-87 (2017)

[4] L. M. F. Purwanto, "KOTA KOLONIAL LAMA SEMARANG ( Tinjauan Umum Sejarah Perkembangan Arsitektur Kota )," Dimens. Tek. Arsit., vol. 33, no. 1, pp. 27- 33 (2005)

[5] A. Y. Puspitasari and W. O. S. K. Ramli, "MASALAH DALAM PENGELOLAAN KOTA LAMA SEMARANG SEBAGAI NOMINASI SITUS WARISAN DUNIA," vol. 15, no. 1 (2018)

[6] P. K. Semarang, "Rencana Tata Bangunan dan Lingkungan (RTBL) Kawasan Kota Lama," (2003)

[7] Semarang City Planning Agency, “Revitalizing Kota Lama Semarang,”( 2015)

[8] A. Keyvanfar et al., "A Sustainable Historic Waterfront Revitalization Decision Support Tool for Attracting Tourists."

[9] G. Nyaupane and D. S. Sustainability, "Ecology, tourism," (2004)

[10] S. Doganer and W. Dupont, "ACCELERATING CULTURAL HERITAGE TOURISM IN SAN ANTONIO: A COMMUNITY-BASED TOURISM DEVELOPMENT PROPOSAL FOR THE MISSIONS HISTORIC DISTRICT," vol. 10, no. 1, pp. 1-19 (2015) 
[11] A. Cirulis, L. Tommaso, D. Paolis, and M. Tutberidze, "Virtualization of digitalized cultural heritage and use case scenario modeling for sustainability promotion of national identity," Procedia - Procedia Comput. Sci., vol. 77, pp. 199-206 (2015)

[12] M. Danisworo and W. Martokusumo, "Revitalisasi Kawasan Kota," Sebuah Catatan dalam, Pengemb. dan Pemanfaat. Kaw. Kota, dalam Newsl. URDI (Urband Reg. Dev. Institute, vol. 13 Januari-Maret 2002, ISSN 1410-3753 (2002)

[13] V. Schmutz and M. A. Elliott, "Tourism and Sustainability in the Evaluation of World Heritage Sites , 1980 - 2010,” pp. 1-14 (2016)

[14] P. M. D. Sotiriadis, "A Strategic Analysis of the Greek Leisure Tourism: Competitive Position, Issues and Challenges,” vol. 6, no. 1, pp. 319-332, 2015.

[15] H. Faculty, "The New Holistic Paradigm and the Sustainability of Historic Cities in Spain : An Approach Based on the World Heritage Cities," (2018)

[16] M. Àngel and G. López, "Urban spatial structure, suburbanization and transportation in Barcelona," J. Urban Econ., vol. 72, pp. 176-190 (2012)

[17] T. F. Jakarta, “Semarang City Bus Network Map,” 2018. [Online]. Available: www.transportforjakarta.com.

[18] Kementerian Agraria dan Tata Ruang, "Peta Bidang Tanah," 2020. [Online]. Available: https://bhumi.atrbpn.go.id/.

[19] J. Wongso, "Strategi Revitalisasi Kawasan Pusat Kota Bukittinggi," J. Tour. Hosp. Essentials J., pp. 1-8 (2002) 